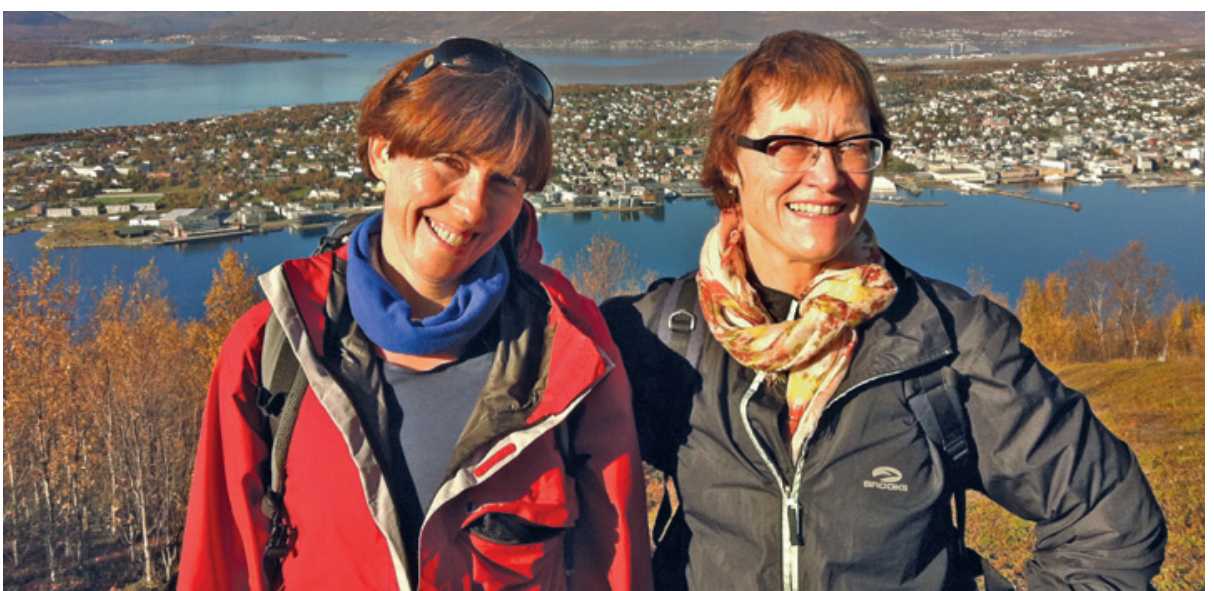

Førsteforfatter Ellen Nordal (til venstre) og sisteforfatter Marite Rygg. Foto Rasmus Fossen Nordal

\title{
Langvarig sykdomsaktivitet ved barneleddgikt
}

\author{
Barneleddgikt er mer kronisk og langvarig enn man tidligere trodde. \\ De fleste barna har god fysisk funksjonsevne, men en femdel utvikler \\ varig sykdomsrelatert skade.
}

Barneleddgikt er en sammensatt sykdomsgruppe som kjennetegnes av kronisk inflammasjon i ledd. Sykdommen, som er vanligst hos jenter, kan ha store konsekvenser for selvopplevd helse og livskvalitet. Langtidsoppfølging av komplette pasientkohorter er en unik kilde til bedre kunnskap om forløp og prognose.

I en nordisk kohortstudie ble 500 barn med barneleddgikt fulgt de første åtte år etter sykdomsdebut. Studien var populasjonsbasert for å få med hele spekteret av sykdom - fra mildere til alvorlige tilfeller. Åtte år etter sykdomsdebut hadde bare $42 \%$ av barna vært uten sykdomsaktivitet og uten medikamenter det siste året. Mange hadde opplevd perioder med inaktiv sykdom med eller uten medikamenter, men så mange som $30 \%$ hadde hatt aktiv sykdom kontinuerlig. Til sammen $58 \%$ av barna hadde brukt ulike sykdomsmodifiserende legemidler, hvorav $48 \%$ metotreksat, og $18 \%$ biologika (biologiske legemidler). Intraartikulære injeksjoner med glukokortikoider, som ofte krever narkose eller sedasjon hos barn, var gitt til om lag tre firedeler av barna.

Barn med få ledd involvert ved sykdomsdebut, men med flere enn fire ledd involvert i forløpet, hadde like dårlig prognose som dem med flerleddstype barneleddgikt fra debut. Rundt en femdel av barna fikk iridosyklitt. Selv om flertallet ikke hadde aktiv leddinflammasjon åtte år etter sykdomsdebut, rapporterte over halvparten sykdomsrelaterte smerter og at livskvaliteten var påvirket siste uke. Etter legens vurdering hadde rundt en femdel en sykdomsrelatert skade.

- Vi planlegger videre oppfølging av denne pasientkohorten, fordi en betydelig andel av barna ser ut til å ha aktiv sykdom over i voksen alder, sier overlege Ellen Nordal ved Barne- og ungdomsklinikken, Universitetssykehuset Nord-Norge, som er førsteforfatter av studien.

\section{Barnerevmatologisk forskning}

Studien er resultat av et langvarig forskningssamarbeid, Nordic Study Group of Pediatric Rheumatology (NoSPeR), mellom barnerevmatologiske sentre i Trondheim, Tromsø, Midt-Sverige, Århus, København og Helsingfors. Artikkelen er skrevet av Ellen Nordal, Marek Zak, Kristiina Aalto, Lillemor Berntson, Anders Fasth, Troels Herlin, Pekka Lahdenne, Susan Nielsen, Bjørn Straume og Marite Rygg. Ellen Nordal er overlege og stipendiat ved Barne- og ungdomsklinikken, Universitetssykehuset Nord-Norge og er i ferd med å avslutte sitt doktorgradsarbeid med førsteamanuensis Marite Rygg ved Norges teknisk-naturvitenskapelige universitet og epidemiolog Bjørn Straume ved Institutt for samfunnsmedisin, Universitetet i Tromsø som veiledere. Marite Rygg og andre medlemmer i NoSPeR-gruppen står også bak andre forskningsprosjekter innen barnerevmatologi.

\section{Erlend Hem}

erlend.hem@medisin.uio.no

Tidsskriftet

\section{Litteratur}

1. Nordal E, Zak M, Aalto $K$ et al. Ongoing disease activity and changing categories in a long-term Nordic cohort study of juvenile idiopathic arthritis. Arthritis Rheum 2011; 63: 2809-18.
Ordforklaringer

Barneleddgikt: Leddinflammasjon i ett eller flere ledd med varighet over seks uker hos et barn under 16 år, hvor andre årsaker er utelukket. Barneleddgikt kalles også juvenil idiopatisk artritt (JIA) og er en heterogen sykdomsgruppe som defineres etter klassifikasjonskriterier fastsatt av International League against Rheumatism (ILAR) i 2001.

Sykdomsmodifiserende legemidler (diseasemodifying anti-rheumatic drugs, DMARD): Metotreksat og TNF- $\alpha$-blokkere er de viktigste sykdomsmodifiserende medikamentene som brukes ved barneleddgikt.

Iridosyklitt: Akutt eller kronisk inflammasjon i fremre del av uvea (iris og corpus ciliare) i øyet. Utvikles hos 10-25\% av barn med barneleddgikt. Kronisk iridosyklitt gir sjelden symptomer. Regelmessige undersøkelser hos øyelege er nødvendig for å stille diagnosen og starte behandling for å unngå synstruende komplikasjoner som katarakt og glaukom.

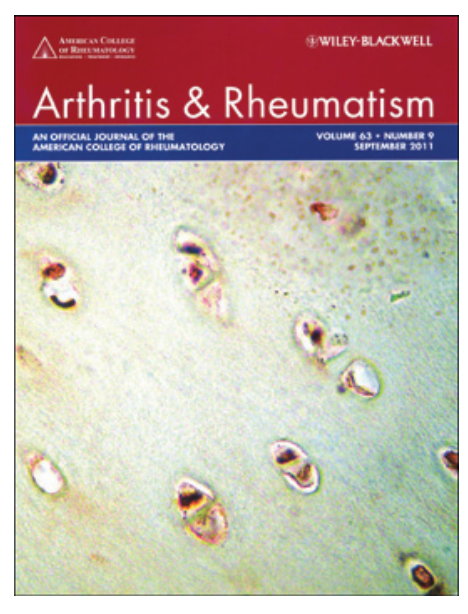

Artikkelen ble publisert i septembernummeret 2011 i Arthritis and Rheumatism, som er et av de høyest rangerte tidsskrifter innen revmatologi 